\title{
TRAÇOS DA ESCRITA INTIMISTA NA POESIA DE FLORBELA
}

\author{
ESPANCA
}

Marcio Jean Fialho de Sousa ${ }^{1}$

Resumo: Este presente artigo tem como objetivo demonstrar como alguns aspectos da escrita intimista se fazem presentes na obra de Florbela Espanca. Para isso, levamos em consideração a perspectiva da escrita de si discutida por Michel Foucault.

Palavras-Chave: escrita intimista; Florbela Espanca; Michel Foucault.

Abstract: This present article aims to show how some aspects of intimate writing are present in the work of Florbela Espanca. In order to analyze them, we will consider the prospect of writing itself discussed by Michel Foucault.

Keywords: written intimate; Florbela Espanca; Michel Foucault.

Por mais que vários indícios da escrita intimista tenham aparecido em diversas épocas da Literatura Portuguesa como, por exemplo, se pode notar desde o Cancioneiro Geral de Garcia de Resende, a Lírica de Camões entre tantos outros que passaram séculos afora, é apenas no século XVIII que, efetivamente, a escrita intimista aparece como temática, se tornando objeto de estudos e pesquisas, passando pelos séculos XIX e XX.

Ao darmos uma maior importância ao século XX, poderemos observar, dentre tantas outras não menos importante, a obra de Florbela Espanca que, perpetuando a tradição intimista, é traspassada quase completamente pelos traços pertinentes a tal escrita, cultivada por grandes escritores e poetas do século XIX assim como Antero de Quental e Guerra Junqueiro.

Em Florbela Espanca, essa temática está ligada às influências de diversos escritores com os quais teve contato, por meio de leituras que realizou durante seus estudos individuais dos quais podemos citar, por exemplo, Alexandre Dumas, Camilo Castelo

\footnotetext{
${ }^{1}$ Mestrando em Letras pelo Programa de Pós-Graduação em Literatura Portuguesa da FFLCH-USP.
} 
Branco e Guerra Junqueiro, que lhe vão desvendando novos horizontes de expressão e sensibilidade.

A obra de Florbela, em sua totalidade, pode ser encarada como uma busca do "eu", um mergulho em busca de um descobrimento de si mesmo que será traduzido por uma obsessão pelo "ser", demonstrado por meio de paradoxos que refletem angústias sentidas pelo sujeito poético diante das incertezas que a vida lhe propõe.

A própria poeta descreve esse sentimento de incerteza, de modo objetivo, numa carta dirigida ao Dr. Guido Battelli em 27 de julho de 1930:

Sou uma céptica que crê em tudo, uma desiludida cheia de ilusões, uma revoltada que aceita, sorridente, todo o mal da vida, uma indiferente a transbordar de ternura. Grave e metódica até a mania, atenta a todas as subtilezas dum raciocínio claro e lúcido, não deixo, no entanto, de ser uma espécie de D. Quixote fêmea a combater moinhos de vento, quimérica e fantástica, sempre enganada e sempre a pedir novas mentiras à vida, num Dom de mim própria que não acaba, que não desfalece, que não cansa! (SOMBRIO, 1947, p. 35)

Embora os poemas de Florbela Espanca possuam uma denotação profundamente confessional, o que pode ser verificado a partir da leitura de sua biografia, não analisaremos sua poesia partindo dessa perspectiva, procuraremos apenas apontar algumas características pertinentes à escrita intimista, dos quais foram selecionados apenas dois.

No conjunto da obra de Florbela Espanca, dois poemas publicados, particularmente, em períodos diferentes e distantes chama-nos a atenção, por receberem o mesmo título: $E u$. A primeira publicação, no Livro de Mágoas, datada de 1919 e a segunda, na coletânea Charneca em Flor, de 1930, esse sendo uma publicação póstuma. Ambos são apresentados, formalmente, com a estrutura do soneto petrarquiano, composto por dois quartetos e dois tercetos, versos decassílabos e esquema de rimas interpoladas em ABBA/ABBA/CDC/EDE.

Partindo para o aspecto semântico, logo numa primeira leitura, no soneto de 1919, o eu lírico diz estar perdido, diz não saber onde está, não sabe o que faz e o que é; já no 
soneto de 1930 o eu lírico se apresenta como aquele que tem consciência de si, como aquele que passou pelo processo do engano ao desengano.

Logo no título de ambos os poemas, o eu lírico traduz o que será abordado no decorrer do soneto, ou seja, nesse caso uma autobiografia, e sendo uma autobiografia é possível prever que o eu lírico não abordará todos os aspectos pertencentes a sua existência. Isso ocorre por vários motivos, dentre os quais, e o mais importante ponto a ser, aqui, abordado, é porque aquele que escreve sobre si mesmo só lhe interessa revelar aquilo que pretende que os outros saibam e pensam sobre si, ou seja, manter a ideia de que o outro já tem formado sobre sua pessoa; em outras palavras, Munira H. Mutran, acerca da autobiografia em Álbum de Retratos, afirma, apropriando-se das palavras de Sturrock:

A autobiografia, diz ele, "é o certificado da passagem de um ser único através do tempo; o teorizador que dela se aproxima cheio de perguntas céticas sobre sua natureza retórica sabe que está jogando um jogo desleal". E o autor conclui alertando para o perigo de se tentar "encontrar igualdades genéricas num tipo de texto que tem por objetivo a diferença". (MUTRAN, 2002, p. 50)

Nos primeiros versos do soneto de 1919, o sujeito poético diz encontrar-se perdido:

Eu sou a que no mundo anda perdida

Eu sou a que na vida não tem norte

O que já nos permite enquadrá-la como poesia intimista, pois é na medida em que o sujeito encontra-se perdido, sem rumo, tornando-se incapaz de fazer qualquer coisa, colocando-se em busca de sentido, do seu rumo, que será caracterizado essa poesia; sendo assim, nesse caso, o sujeito poético não se encontra perdido em algum lugar, mas dentro de si próprio precisando encontrar-se, informação essa que provém do título do próprio soneto.

Dessa forma, o eu lírico encontra-se no isolamento, está realizando a anacorese (FOUCALT, 1992, p.130). Essa ideia de anacorese, ação expressa em grego, empregada pelo verbo anakhoreîn, designa o ato de se afastar, se refugiar, se retirar para o deserto. Perspectiva advinda das práticas cristãs dos eremitas dos primeiros séculos e documentada por Atanásio no século IV. 
Com a apologia da fuga, o retirante (anacoreta) "adquire sua constituição como alguém que é injustamente perseguido por seus inimigos, heréticos ou idólatras, e que justificadamente se retira." (JÚNIOR, 2008, p. 103).

Segundo Michel Foucault, a anacorese se dá, entre outras coisas, pelo fato de que a presença alheia provoca um constrangimento no indivíduo, que, por sua vez expressará seus sentimentos e angústias por intermédio da escrita (hypomnemata), se desenvolve num momento de recolhimento interior, seguido pelo contato com o outro. Esse último aspecto é de extrema importância nos escritos de Foucault, pois o cuidado de si não é visto como uma atividade solitária. Frédéric Gros, ao abordar a importância do outro na obra de Michel Foucault, diz que essa interação é uma forma de intensificar a relação social: "Não se trata de renunciar ao mundo e aos outros, mas de modular de outro modo esta relação com os outros pelo cuidado de si." (GROS, 2006, p. 132)

Dessa forma, tendo em vista que no soneto de 1919, o eu lírico encontra-se está perdido, pressupõe-se que está sozinho, não tem com quem falar, e se está num estado de isolamento, coloca-se numa posição de superioridade. Nesse sentido, José Régio (1987) classifica a poesia de Florbela como narcisista, pois o eu lírico encontra-se consigo mesmo, em busca de si mesmo, porém perdido, não há o outro, apenas o eu.

José Régio relega o narcisismo a um primeiro grau da feminilidade de Florbela Espanca, como que precedendo à voluptuosidade veemente que vem intensificar seu desempenho feminino (RÉGIO,1987). O que para Freud seria uma qualidade negativa, pois, segundo diz, todo e qualquer narcisismo não favorece a entrega amorosa ou o recrudescimento sexual feminino; voltadas para si mesmas, as mulheres tomadas do que ele chama de "narcisismo primitivo", "só amam, na realidade, a si mesmas e com a mesma intensidade com que o homem as amam. Não necessitam amar e sim serem amadas, e assim aceitam o homem que preenche essa condição.” (FREUD, s.d, p. 35)

Nos dois versos seguintes dessa primeira estrofe, o eu lírico relata: "Sou a irmã do Sonho, e desta sorte/ Sou a crucificada... a dolorida..." Além de não saber onde está, o sujeito é ainda a irmã do sonho, ou seja, da ilusão, do irreal e, ainda, é a dolorida, é a que 
sofre. A procura de conhecer a si mesmo se beneficia do sentimento doloroso. É a partir do momento em que o eu lírico busca se conhecer que a dor se potencializa, são os traços da dor que atuam como força alentadora e é desta estratégia da dor que o sujeito não se mostra fingido, mas expõe os sentimentos verdadeiros do existir.

Segundo Ruth Amossy (2005), todo ato de tomar a palavra implica a construção de uma imagem de si; nesse poema de Florbela Espanca, o sujeito poético constrói uma autoimagem a partir da solidão e da dor.

Na segunda estrofe:

Sombra de névoa tênue e esvaecida,

E que o destino amargo, triste e forte,

Impele brutalmente para a morte!

Alma de luto sempre incompreendida!...

Como já citado anteriormente, o sujeito poético se apresenta como aquele que sofre no presente, sofreu no passado "Alma de luto" e possui a consciência de que continuará sofrendo, pois, como diz no segundo quarteto, seu destino é amargo e triste, sem contar a sombra que o cobre friamente para enfraquecê-lo diante deste destino que o impele para a morte de modo violento, destino esse que é "triste e forte".

Sou aquela que passa e ninguém vê...

Sou a que chamam triste sem o ser...

Sou a que chora sem saber porquê...

Sou talvez a visão que Alguém sonhou,

Alguém que veio ao mundo pra me ver 
E que nunca na vida me encontrou!

Nos tercetos finais conclui-se que é uma pessoa desprezível, insignificante. O eu lírico diz ser visto como um ser triste quando afirma não ser, mas, em contrapartida, se vê chorando sem saber por que. É incompreendido por si mesmo e pelo outro. Aqui é possível observar claramente os paradoxos que continham na carta de Florbela ao Dr. Guidio, anteriormente apresentada, quando, por exemplo, dizia ser uma cética que crê em tudo.

Ainda nos tercetos, o sujeito poético busca evadir-se da exterioridade, "passa e ninguém vê", o que marca uma dispersão. Crê que no íntimo é que estaria sua face verdadeira, na perspectiva do encontro consigo mesma. Pensa ser uma visão, ou a que veio ao mundo e não seguiu o seu destino por estar perdida e nunca ter sido encontrada.

Já no soneto de 1930, o eu lírico demonstra ser mais consciente, diz saber que não se conhecia no passado, mas agora se conhece:

Até agora eu não me conhecia.

Julgava que era Eu e eu não era

Aquela que em meus versos descrevera

Tão clara como a fonte e como o dia.

Em seguida, o eu lírico passa pelo processo do engano ao desengano, ao que Platão dizia com o Mito da Caverna, passou do mundo idealístico ao mundo real; em primeira instância não sabia quem era, por outro lado afirma que mesmo se soubesse não diria:

\footnotetext{
Mas que eu não era Eu não o sabia

E, mesmo que o soubesse, o não dissera...
}

Olhos fitos em rútila quimera 
Andava atrás de mim... e não me via!

Segundo Foucault (1992), essa atitude se enquadraria no fato de dar ao que se viu, ou pensou, um olhar possível (Foucault, 1992, p. 131).

Ainda nos tercetos finais, o eu lírico conclui dizendo que a passagem do engano ao desengano se dá pela presença do outro, foi por intermédio do outro que ele se encontrou, foi no outro que se refletiu, foi através do outro que se reconheceu:

Andava a procurar-me - pobre louca! -

E achei o meu olhar no teu olhar,

E a minha boca sobre a tua boca!

E esta ânsia de viver, que nada acalma,

É a chama da tua alma a esbrasear

As apagadas cinzas da minha alma!

Depois de ter passado pelo processo do engano ao desengano, no último terceto, o eu lírico sente vontade de viver depois de ter se encontrado e ter tido contato com o outro.

A análise desses dois sonetos nos dá uma visão geral da obra de Florbela Espanca, de modo que possamos integrá-la à escrita intimista, a escrita que tem por lema um eu lírico que busca a si mesmo. Em Florbela Espanca, o eu lírico é apresentado, em geral, por uma solidão incurável que sustenta sua própria natureza, gerando apoios que podem se dar pelo processo de anacorese ao atenuar os perigos da solidão e ter como companheiro o papel, no ato de escrever; punições ao se defender de pensamentos considerados impuros, por vergonha de tê-los conhecido; tendo a dor como cúmplice e força motriz de suas mais profundas aptidões, tudo isso sem levar em consideração uma possível e verdadeira análise crítica a partir de aspectos biográficos da poesia de Florbela Espanca. 


\section{REFERÊNCIAS BIBLIOGRÁFICAS}

AMOSSY, Ruth. Imagem de si no discurso: a construção do ethos. São Paulo: Ed. Contexto, 2005.

ESPANCA, Florbela. Melhores Poemas. Seleção: Zina C. Belloti. São Paulo: Global, 2005.

FOUCALT, Michel. “A escrita de si”. In. O que é um autor? Lisboa: Veja, 1992.

FREUD, Sigmund. Introdução ao narcisismo. In: Obras completas de Sigmund Freud, v. VII. Trad. De C. de Magalhães de Freitas. RJ: Delta, s.d.

GROS, Frédéric. "O cuidado de si em Michel Foucault". In. Figuras de Foucault. Belo Horizonte: Autêntica, 2006., p. 127 - 138.

JÚNIOR, Pedro Ipiranga. "Da cidade ao deserto: a constituição do espaço eremita." In. Revista Archai: revista sobre as origens do pensamento ocidental. N.01 (jul 2008). Brasília, 2008 [on-line]. (http://archai.unb.br/revista/pdf/01/01-pedro.pdf $\underline{28 / 04 / 2010}-15 \mathrm{~h} 44)$

MUTRAN, Munira H. Álbum de Retratos: George Moore,Oscar Wilde e William Butter Yeats no fim do século XIX: um momento cultural. SP: Ed. Humanitas, 2002.

RÉGIO, José. "Estudo crítico". In: ESPANCA, F. Sonetos.4 ed. Rio de Janeiro: Bertrand Brasil, 1987.

SOMBRIO, Carlos. Florbela Espanca. S.1. Edições Homo, 1947. 